\title{
Application of Traditional Games: How Does It Affect the Children's Fundamental Motor Skills?
}

\author{
Rifqi Festiawan \\ Department of Physical Education, Faculty of Health Science, Jenderal Soedirman University, \\ Indonesia. \\ * Correspondence author. E-mail: rifqi.festiawan@ unsoed.ac.id
}

Received: 25 September 2020; Revised: 29 October 2020; Accepted: 01 November 2020

https://doi.org/10.24036/MensSana.050220.08

\begin{abstract}
This study aims to determine the effect of implementing traditional game learning models on improving children's basic motor skills. The research method used is the experimental method. The designs used are the Pre-test and Post-test Group Design. The study population consisted of two classes with 60 students and the sampling technique used simple random sampling with a sample size of 30 students. The test instruments used in this study included: 1) 4 x 10-meter shuttle run test, 2) throw-and-catch test at a distance of 1 meter from the wall, 3) Stork stand test positional balance, 4.) Test 30 sprint meter. The data analysis technique used is the prerequisite test which includes data normality test and data homogeneity test and hypothesis testing using paired t-test. The results showed an effect of traditional game-based learning models on the improvement of children's Fundamental Motor Skills as evidenced by $\mathrm{p}$ value $=0.001$. Also, from the control group data it is known that there is no significant effect of conventional learning on improving children's Fundamental Motor Skills as evidenced by $\mathrm{p}$ value $=0.072$, with these results it can be concluded that traditional game-based learning models are proven to improve children's fundamental motor skills, and can be used as an alternative to the learning process that is more effective than conventional learning.
\end{abstract}

\section{Keywords: Traditional Games, Physical Education, Learning, Fundamental Motor Skill}

\section{INTRODUCTION}

Playing is an activity that is very familiar with human life (Kamaludin et al., 2020). When humans are in the process of forming themselves from childhood to adulthood, not one of the human individuals is not familiar with games, one of which is a game that used to be called traditional games without being touched by modernization (Festiawan et al., 2019).

Electronic games versus traditional games do not appear on the surface (it becomes an intense debate), but certain groups realize that in this era of globalization, the active values in traditional children's games need to be explored again because this new game is considered to further alienate children from the active value as in traditional children's games (Sukirman, 2008).

Traditional games are an example of thousands of traditional games in Indonesia. However, these traditional games are now being eroded little by little, especially in cities, perhaps for children today, many are not familiar with traditional games are games inherited from the ancestors of the Indonesian people (Festiawan \& Arovah, 2020). Every region in Indonesia has traditional games, traditional games in each region are usually not the same, unlike modern games today, such as technology games, which on average have similarities, such as games on computers and cellphones.

Traditional games in Indonesia seem to face a less bright future. The apparent trend is that various play forms are now unknown to many children, being played very rarely. Only certain games are still widely played (Sukirman Dharmamulya, et al 2008). Many parents think that learning something in non-formal classes is more useful than playing.

Even though many things can be taken advantage of from traditional games, one of which is tools that are easy to get and allow children to play with them, at that time for children to release their creative ideas. In this game, the child's soul will be seen in its entirety. The cheerful atmosphere that is built will give 
birth and produce a pleasant togetherness. This is what causes people's lives to be harmonious (Ajun Khamdani, 2010).

Harmony is built together, in the sense that to maintain the game, they make their own rules that are agreed upon together, if someone violates they will be given sanctions and if they realize the mistakes they have made, their friends will be tolerated. On the other hand, the learning process has been embedded in traditional games, the players have learned to obey the rules of fair play. A learning process in life that recognizes mutual acceptance and forgiveness (Ajun Khamdani, 2010).

Children's skills are always honed, children are conditioned to make games from various materials around them, the use of play materials is always inseparable from nature, which creates interactions between children and their environment so close. Togetherness with nature is an important part of the process of introducing young people to their environment. Thus the muscles or motor sensors will be more honed too, on the other hand, the creative process is the initial stage to hone children's creativity and imagination to get a room for growth (Dinalisa, 2011).

To optimize learning outcomes motoric physical development, especially in the field of gross motor skills such as jumping, running, dancing, playing ball, and playing games a handson approach should be needed to study or learn while playing. By playing children have the opportunity to explore, discovering, expressing feelings, creating, learning in a fun way. Apart from that playing helps children control themselves, other people, and the environment.

By using traditional game crank can train the child's ability to read body movements, move the body, train agility and the child's agility in the game improves communication skills and composing skills good strategy, release the child's emotions and train children to learn in groups. Besides, kids will appear active in learning motor physical development and have an interest and motivation to play the game with a happy heart.

In the gross motoric development of early childhood, we need to know what forms of motor skills a child. Motor development is the process of a child learning to move the limbs skillfully. Children learn from the teacher about some movement patterns they can do that can train dexterity, speed, strength, flexibility, and accuracy of hand and eye coordination. Developing motor skills is needed by children so that they can grow and develop optimally.

There are three motor skills of children, including 1. Locomotor skills: walking, running, jumping, sliding. 2. Non-locomotor skills: lifting, pushing, curving, swinging, pulling. 3. Skills to project and receive/catch objects: catching, throwing (Sudjiono, 2015). The motor development of children is divided into two parts: gross motor movements and fine motor movements.

Gross motor movements are formed when children begin to have coordination and balance that are almost like adults. The term motor (motor) refers to the biological and mechanical factors that influence movement. The term motion refers to the actual changes that occur in an observable part of the body. Thus, motoric is an outward ability that a person has to change various body positions. Gross motor movement is the ability to change various body positions using large muscles. Examples of gross motor skills are walking, running, jumping, jumping (Masganti, 2015). This means that the physical ability that a person carries from birth is a gift that must be given treatment or action to maximize the child's gross motor skills.

Different motor skills play different roles in adapting a child's social and personality. For example, skills function to help children to gain independence, while others work to gain social acceptance. Elizabeth B. Hurlock (2009). Since it is not possible to simultaneously acquire motor skills, the child will focus on learning skills to help develop a form of adjustment. Children's sports activities are often not realized, due to sports movements in playing activities (Cattuzzo et al., 2016).

Play activities involving aspects of physical skills (physical skills) and gross motor skills tend to be similar to sports activities. Playing activities for children aged 5 years and over are in the Golden Age, which is a period when the child's physiology is very sensitive to receiving stimuli. If the Golden Age is missed, the best opportunity for the child has been missed. According to John W. Santrock (2007: 214) "at the age of 5 years, children prefer adventure more than when children are 4 years old. It is not uncommon for a confident 5 years old to perform a terrifying scene climbing an 
object. Children run fast and enjoy racing with each other and their parents".

Different motor skills play different roles in adapting a child's social and personality $\left(\mathrm{O}^{\prime}\right.$ Brien et al., 2016). For example, skills function to help children to gain independence, while others function to gain social acceptance. Hurlock (2009). Since it is not possible to simultaneously acquire motor skills, the child will focus on learning skills that will help acquire a form of adjustment.

Children's sports activities are often not realized, due to sports movements in playing activities (Abbott et al., 2002). Play activities involving aspects of physical skills (physical skills) and gross motor skills tend to be similar to sports activities. Playing activities for children aged 5 years and over are in the Golden Age, which is a period when the child's physiology is very sensitive to receiving stimuli, and if the Golden Age is missed, the best opportunity for the child has been missed (Webster \& Ulrich, 2017).

According to Santrock (2007) "at the age of 5 years, children prefer adventure more than when children are 4 years old. It is not uncommon for a confident 5 years old to perform a terrifying scene climbing an object (Freitas et al., 2018). Children run fast and enjoy racing with each other and their parents." By mid-childhood children's motor skills are more refined than when they were in early childhood, children can play sports.

Only a few children can be flexible in playing a difficult game such as passing a tennis ball over the net. But when they are 10 or 11 years old most children can learn to play the sport (Festiawan et al., 2019). Running, climbing, skipping, swimming, bicycle riding, and skating are just a few of the many physical skills elementary school children can master. If mastered gross motor skills involve large muscle activity, boys usually outperform girls (Santrock, 2007).

As the child goes through the elementary school years, the child gains more control over the body and can sit and pay attention for long periods. However, primary school children are far from physically mature and must remain active. Elementary school children become more tired from sitting for long periods than running, jumping, or riding a bicycle. Physical actions are important for these children to improve their developing skills, such as hitting a ball, jumping rope, or balancing on aboard. Primary school children must be more involved in active than passive activities.

Regular exercise is one way to encourage children to be active and develop motor skills, all of which can play an important role in a child's life. Motion is something that is displayed by humans in real and observable ways. However, the background for the motion shown in real action in performance is very diverse according to the nature of human existence and needs full of differences.

Playing is one way to improve the child's ability to move, by moving the large muscles of the child stronger and thus the movement of the child can be controlled by himself (Priklerová \& Kucharik, 2015). Any activity directed at an end goal other than fun is a game that is only for fun so that children are excited about a game. Game is a physical activity, by moving the gross motor skills in children will always be honed and become better and better (Vlahov et al., 2014).

\section{METHOD}

The research method used in this study uses the experimental research method. The research design used in this study was The Randomize Pretest-Posttest Control Group Design. This design involves two groups that were studied to be used as the experimental group and the control group. Both groups were measured twice, namely at the pretest and posttest. The following is an overview of this design:

Table 1. The Randomize Pretest-Posttest Control Group Design

\begin{tabular}{|l|lll|}
\hline Experimental group & O1 & $X$ & O2 \\
\hline Control group & O1 & C & O2 \\
\hline
\end{tabular}

(Source: Fraenkel, Wallen, \& Hyun., 2012)

Description:

O1: Pretest

O2: Posttest

X: Treatment (Application of traditional sport based) $\mathrm{C}$ : Conventional Learning

The instrument used in this study was a motor ability test which consisted of 4 test items, namely 1) 4 x 10-meter shuttle run test, 2) throwand-catch test at a distance of 1 meter from the wall, 3) Stork stand test positional balance, 4.) Test 30 meter sprint. Procedures need to be broken down by type of research. How research is done and the data will be obtained, it should be described in this section. This study's technique 
analysis data include a prerequisite test that includes a data effectiveness test and data homogenization test, followed by a hypothesis test using a paired t-test.

\section{RESULTS AND DISCUSSION \\ Research result \\ Data from the Pretest-Postest Results of the Treatment Group}

This descriptive data discusses the results of the pre-test and post-test regarding the mean, standard deviation, variance, maximum value, and minimum value and variance. The pretest data of the treatment group can be seen in Table 2.

Table 2. Data on the pretest and posttest results for the treatment group

\begin{tabular}{|c|c|c|c|c|c|}
\hline & & Mean & $\begin{array}{c}\text { Std } \\
\text { Deviasi }\end{array}$ & Max & Min \\
\hline \multirow{4}{*}{ Pre-test } & Agility & 27,86 & 4,31 & 33,63 & 21,2 \\
\cline { 2 - 6 } & Balance & 28,78 & 23,91 & 120,8 & 0 \\
\cline { 2 - 6 } & Coordination & 16,05 & 7,96 & 31 & 0 \\
\cline { 2 - 6 } & Speed & 5,69 & 1,02 & 8,31 & 4,87 \\
\hline \multirow{5}{*}{ Post-test } & Agility & 27,67 & 4,26 & 36,53 & 24,4 \\
\cline { 2 - 6 } & Balance & 37,11 & 54,67 & 252,6 & 0 \\
\cline { 2 - 6 } & Coordination & 21,05 & 7,62 & 33 & 4 \\
\cline { 2 - 6 } & Speed & 5,48 & 1,12 & 9,39 & 4,5 \\
\hline
\end{tabular}

Based on the analysis of table 2 above, it can be seen that the pre-test result of the agility test (Shuttle run) is (Mean) 27.86 with (Standard Deviation) 4.31, the fastest time is 21.16 seconds and the late time is 33, 63 seconds. As for the post-test results of agility (shuttle run) is (Mean) 27.67 with (Standard Deviation) 4.26 and the fastest vulnerable time is 24.43 seconds and late time is 36.53 seconds.

The pre-test result of the balance test (Stork stand position balance) is (Mean) 28.78 with (Standard Deviation) 23.91 and the longest time is 120.76 seconds and the fastest time is 0.00 seconds. Meanwhile, the post-test result of the balance (Stork stand position balance) is (Mean) 37.11 with (Standard Deviation) 54.67 and the longest time is 252.64 seconds and the fastest time is 0.00 seconds.

The pre-test result of the coordination test (throwing catch using a tennis ball with a wall of 1 meter) is (Mean) 16.05 with (Standard Deviation) 7.96 and the maximum catch is 31 times and the minimum catch is 0 times. Meanwhile, the post-test results of the coordination (throw and catch using a tennis ball with a wall of 1 meter) are (Mean) 21.05 with (Standard Deviation) 7.62 and the maximum catch is 33 times and the minimum catch is 4 times.

The pre-test result of the speed test (Sprint) is (Mean) 5.69 with (Standard Deviation) 1.02 and the fastest vulnerable time is 4.87 seconds and the late time is 8.31 seconds. Meanwhile, the post-test result of the speed (Sprint) is (Mean) 5.48 with (Standard Deviation) 1.12 and the fastest vulnerable time is 4.50 seconds and the late time is 9.39 seconds.

\section{Data from the Pretest-Postest Control Group}

This descriptive data discusses the results of the pre-test and post-test regarding the mean, standard deviation, variance, maximum value, and minimum value and variance. The pretest data of the control group can be seen in Table 3 .

Table 3. Data on the results of the control group pretest and posttest

\begin{tabular}{|c|c|c|c|c|c|}
\hline \multicolumn{1}{|c|}{ pretest and posttest } \\
& & Mean & $\begin{array}{c}\text { Std } \\
\text { Deviasi }\end{array}$ & Max & Min \\
\hline \multirow{5}{*}{ Pre-test } & Agility & 26,71 & 4,01 & 32,93 & 20,12 \\
\cline { 2 - 6 } & Balance & 27,63 & 23,12 & 115,8 & 0 \\
\cline { 2 - 6 } & Coordination & 15,93 & 7,62 & 31 & 0 \\
\cline { 2 - 6 } & Speed & 5,71 & 1,12 & 8,12 & 4,51 \\
\hline \multirow{5}{*}{ Post-test } & Agility & 26,81 & 4,12 & 33,99 & 20,32 \\
\cline { 2 - 6 } & Balance & 27,90 & 23,23 & 116,7 & 0 \\
\cline { 2 - 6 } & Coordination & 16,05 & 7,66 & 32 & 4 \\
\cline { 2 - 6 } & Speed & 5,74 & 1,16 & 8,15 & 4,47 \\
\hline
\end{tabular}

Based on the analysis of table 3 above, it can be seen that the pre-test results of the agility test (Shuttle run) are (Mean) 26.71 with (Standard Deviation) 4.01 and the fastest vulnerable time is 20.12 seconds and the late time is 32.93 seconds. Meanwhile, the post-test result of the agility test (Shuttle run) is (Mean) 26.81 with (Standard Deviation) 4.12 and the fastest vulnerable time is 20.32 seconds and the late time is 33.99 seconds.

The pre-test result of the balance test (Stork stand position balance) is (Mean) 27.63 with (Standard Deviation) 23.12 and the longest time is 115.8 seconds and the fastest time is 0.00 seconds. Meanwhile, the post-test result of the balance (Stork stand position balance) is (Mean) 27.90 with (Standard Deviation) 23.23 and the longest time is 116.7 seconds and the fastest time is 0.00 seconds.

The pre-test result of the coordination test (throwing catch using a tennis ball with a wall of 
1 meter) is (Mean) 15.93 with (Standard Deviation) 7.62 and the maximum catch is 31 times and the minimum catch is 0 times. Meanwhile, the post-test results of coordination (throw and catch using a tennis ball with a wall of 1 meter) are (Mean) 21.05 with (Standard Deviation) 7.62 and the maximum catch is 32 times and the minimum catch is 4 times.

The pre-test result of the speed test (Sprint) is (Mean) 5.71 with (Standard Deviation) 1.12 and the fastest vulnerable time is 4.51 seconds and the late time is 8.12 seconds. Meanwhile, the post-test result of the speed (Sprint) is (Mean) 5.74 with (Standard Deviation) 1.16 and the fastest vulnerable time is 4.47 seconds and the late time is 8.15 seconds.

\section{Prerequisite Test}

The prerequisite test in this study consisted of a data normality test and a data homogeneity test, the data obtained included:

\section{Data Normality Test}

The data normality test is one of the tests that aims to determine whether the data in the study is normally distributed or not. Data is normally distributed if the significance value is greater than 0.05 or (Sig.> 0.05 ), on the other hand, if the data is smaller than 0.05 or (Sig. $<0.05$ ), the data is said to be abnormal. In this study, the normality test was carried out using SPSS assistance with the Shapiro Wilk test. The results of the normality test can be seen in Table 4.

Table 4. Data on Normality Test Results

\begin{tabular}{|c|c|c|c|c|}
\hline DATA & Statistic & $D f$ & Sig & Kesimpulan \\
\hline $\begin{array}{l}\text { Pretest } \\
\text { Kelompok }\end{array}$ & ,951 & 10 & ,669 & Normal \\
\hline $\begin{array}{l}\text { Treatment } \\
\text { Postest } \\
\text { Kelompok }\end{array}$ & ,959 & 10 & 874 & Normal \\
\hline $\begin{array}{l}\text { Treatment } \\
\text { Postest } \\
\text { Kelompok } \\
\text { Kontrol }\end{array}$ & ,971 & 10 & ,591 & Normal \\
\hline $\begin{array}{l}\text { Postest } \\
\text { Kelompok } \\
\text { Kontrol }\end{array}$ & ,941 & 10 & ,609 & Normal \\
\hline
\end{tabular}

From the data in Table 4, it can be concluded that the Sig values of the pretest and posttest of the Treatment and Control groups are all greater than 0.05 or the Sig value> 0.05, it can be concluded that the data for the two groups are normally distributed.

Data Homogeneity Tests
The data homogeneity test is one of the tests used to determine the similarity of the study population's variants. A homogeneity test of this data was carried out with the help of SPSS. The decision-making criteria are if the value of Sig> 0.05 or $t$ count $<t$ table means that the sample is homogeneous.

Table 5. Data on Homogeneity Test Results

\begin{tabular}{|c|c|c|c|c|c|}
\hline DATA & $\begin{array}{l}\text { Levene } \\
\text { Statistic }\end{array}$ & $d f 1$ & $d f 2$ & Sig. & Kesimpulan \\
\hline $\begin{array}{l}\text { Pretest } \\
\text { Kelompok } \\
\text { Treatment }\end{array}$ & ,398 & 1 & 10 & ,789 & Homogen \\
\hline $\begin{array}{l}\text { Postest } \\
\text { Kelompok } \\
\text { Treatment }\end{array}$ & ,468 & 1 & 10 &, 742 & Homogen \\
\hline $\begin{array}{l}\text { Postest } \\
\text { Kelompok } \\
\text { Kontrol }\end{array}$ & ,472 & 1 & 10 & ,780 & Homogen \\
\hline $\begin{array}{l}\text { Postest } \\
\text { Kelompok } \\
\text { Kontrol }\end{array}$ & ,497 & 1 & 10 & ,722 & Homogen \\
\hline
\end{tabular}

From the data in Table 5, it can be concluded that the Sig values of the pretest and posttest of the Treatment group and the control group are all greater than 0.05 or the Sig value> 0.05 and it can be concluded that the variants of the two groups are homogeneous.

\section{Hypothesis testing}

The data analysis technique used is the $\mathrm{t}$ test with a significance of 5\%. There is one type of t-test performed, namely a Paired t-test.

Table 7. Hasil Uji Paired T-Test

\begin{tabular}{llr}
\hline Paired Sampled T-Test & \\
\hline & & Sig. (2-tailed) \\
\hline Pair 1 & $\begin{array}{l}\text { Treatment Group Pretest } \\
\text { Treatment Group Posttest }\end{array}$ &, 001 \\
Pair 2 & $\begin{array}{l}\text { Control Group Pretest } \\
\text { Control Group Posttest }\end{array}$ &, 072 \\
& Based
\end{tabular}

Based on the paired t-test analysis (Table 7), the Sig. (2-tailed) The treatment group was 0.001 and the results were Sig. (2-tailed) the control group was 0.072 . With these results, the treatment group has a Sig value. $<0.05$, while the control group had a Sig. $>0.05$, so it can be concluded that there is a significant influence between traditional sports provision on improving children's fundamental motor skills.

\section{Discussion}

The long process faced by children in their growth and development. Growth and development is a unified unity in coloring the rate of development of the child day by day, month after month, and year after year. We realize that 
both are important things for developing a child. We simply understand that growth has to do with the physical which can be observed while development is related to children's abilities. both have their respective functions and duties in supporting their developing child. the two go hand in hand and are related.

Pleasure in exploring and like knowing no fear, then everything the movements taught to the child will be considered a game fun. The first five years of growth and development of the child are called the golden age because at that time the physical condition and all abilities the child is developing fast. The rapid development experienced by the physical child a sign that the child is an active individual that we should be parents must know how to direct the motor activity of the child.

This study aims to determine the effect of traditional game-based learning models on improving children's fundamental motor skills. The research was started by doing a pretest, after that the treatment was given using traditional game-based learning methods and conventional learning which had a balanced portion between the two learning processes, then in the final stage, it was followed by a posttest.

This study uses the research design "Pretest-Posttest Control Group Design", a research design that functions to determine the effect of each group before and after treatment and then compares the difference in influence through the paired results t-test so that the differences can be known more accurately.

\section{Hypothesis of the Effect of Traditional Game- Based Learning Model on the Improvement of Children's Motor Skills Fundamental}

Based on the test result above, it can be seen that the pre-test result of the agility test (Shuttle run) is (Mean) 27.86 with (Standard Deviation) 4.31, the fastest time is 21.16 seconds and the late time is 33,63 seconds. As for the post-test results of agility (shuttle run) is (Mean) 27.67 with (Standard Deviation) 4.26 and the fastest vulnerable time is 24.43 seconds and late time is 36.53 seconds.

The pre-test result of the balance test (Stork stand position balance) is (Mean) 28.78 with (Standard Deviation) 23.91 and the longest time is 120.76 seconds and the fastest time is 0.00 seconds. Meanwhile, the post-test result of the balance (Stork stand position balance) is
(Mean) 37.11 with (Standard Deviation) 54.67 and the longest time is 252.64 seconds and the fastest time is 0.00 seconds. The pre-test result of the coordination test (throwing catch using a tennis ball with a wall of 1 meter) is (Mean) 16.05 with (Standard Deviation) 7.96 and the maximum catch is 31 times and the minimum catch is 0 times.

Meanwhile, the post-test results of the coordination (throw and catch using a tennis ball with a wall of 1 meter) are (Mean) 21.05 with (Standard Deviation) 7.62 and the maximum catch is 33 times and the minimum catch is 4 times. The pre-test result of the speed test (Sprint) is (Mean) 5.69 with (Standard Deviation) 1.02 and the fastest vulnerable time is 4.87 seconds and the late time is 8.31 seconds. Meanwhile, the post-test result of the speed (Sprint) is (Mean) 5.48 with (Standard Deviation) 1.12 and the fastest vulnerable time is 4.50 seconds and the late time is 9.39 seconds.

From these data then tested by Paired t-test and obtained t-test results with the value of Sig. (2-tailed) treatment group was 0.001. So that from these results it can be seen that the Sig. smaller than 0.05 or $0.001<0.05$, this means that traditional game-based learning models have a significant effect on improving children's fundamental motor skills.

This is in line with several previous studies including research from (Rusmawati, 2016), which said a significant effect of the application of traditional games on basic motor movements in learning PJOK in grade V SDN Margomulyo 1 Bojonegoro. Evidenced by the Wilcoxon test results, namely Zhitung $(-2,770)$ is greater than Ztabel (-1.96). Meanwhile, (Akbar, 2013) concluded that there is an influence of traditional games of bentengan, kasti, and gobak sodor on the improvement of gross motoric movements in the form of power, running, and agility in fifthgrade elementary school male students.

Another study from (Puspitasari, 2016) states that based on the results of research and data analysis that has been carried out with the Utest (Mann - Whitney U Test), the number of $n 1$ $=17$ and $\mathrm{n} 2=17$ is obtained in table 77 , so the calculated price is smaller than $\mathrm{T}$ table so that $\mathrm{Ho}$ is rejected and $\mathrm{Ha}$ is accepted. Thus, it means that the traditional game of rubber affects long jump learning.

Based on the research, it can be seen that the child's gross motor skills before on cycle I to 
cycle II shows enhancement. The child completeness cycle only reached 8 children while in cycle II completeness reached 11 children Through the traditional game, this crank can develop children's logical intelligence. Game cranks also train children to count and determine the steps that must be passed and children become more creative because of play traditional usually made directly by the players.

They use things, objects, or plants that are around the para player. It encourages them to do more creatively creating game tools. With this research, researchers can prove a theory that describes in detail children's motor systematics, namely Dynamic SystemTheory developed by Thelen \& whitener. The theory reveals that to build motor skills children must perceive something in that environment motivate them to do something and use their perceptions to move. Motor skills represent a child's wishes. For example, when the child sees toys with a motley, the child perceives in his brain that he wants to play with it. These perceptions motivate children to do something, which is to move.

From the results of research and several previous studies, it can be described that traditional games can be applied to physical education learning, as an alternative to improve children's fundamental motor skills, by implementing good treatments.

\section{CONCLUSION}

Based on the study results, it can be concluded that there is a significant effect of traditional sports-based learning methods on improving children's fundamental motor skills.

\section{CITATIONS AND REFERENCES}

Abbott, A., Collins, D., Martindale, R., \& Sowerby, K. (2002). Talent Identification and Development: An Academic Review A report for sportscotland by The University of Edinburgh. Sport Scotland, August, 1103.

Akbar, R. M. (2013). Pengaruh Olahraga Tradisional Bebentengan Terhadap Kemampuan Motorik (Motor Ability) Anak Usia 6-8 Tahun Universitas Pendidikan Indonesia | repository.upi.edu | perpustakaan.upi.edu.

Universitas
Astorino, T. A., Edmunds, R. M., Clark, A., King, L., Gallant, R. A., Namm, S., Fischer, A., \& Wood, K. M. (2017). High-Intensity Interval Training Increases Cardiac Output and V-O2max. Medicine and Science in Sports and Exercise, 49(2), 265-273. https://doi.org/10.1249/MSS.000000000000 1099

Batacan, R. B., Duncan, M. J., Dalbo, V. J., Tucker, P. S., \& Fenning, A. S. (2017). Effects of high-intensity interval training on cardiometabolic health: A systematic review and meta-analysis of intervention studies. British Journal of Sports Medicine, 51(6), 494-503. https://doi.org/10.1136/bjsports2015-095841

Cattuzzo, M. T., dos Santos Henrique, R., Ré, A. H. N., de Oliveira, I. S., Melo, B. M., de Sousa Moura, M., de Araújo, R. C., \& Stodden, D. (2016). Motor competence and health related physical fitness in youth: A systematic review. Journal of Science and Medicine in Sport, 19(2), 123-129. https://doi.org/10.1016/j.jsams.2014.12.004

Festiawan, R., \& Arovah, N. I. (2020). Pengembangan "Buku Saku Pintar Gizi " Untuk Siswa: Alternatif Media Pembelajaran untuk Meningkatkan Pengetahuan Gizi Olahraga. Physical Activity Journal, 2(1), 188-201. https://doi.org/https://doi.org/10.32424/1.paj u.2020.1.2.2436 Abstrak

Festiawan, R., Ngadiman, N., Kusuma, I. J., Nurcahyo, P. J., \& Kusnandar, K. (2019). Pengembangan Model Pembelajaran Pendidikan Jasmani Berbasis Games, Education, and Visualisation (GEV) Untuk Meningkatkan Pengetahuan Kesehatan Reproduksi Remaja. Jendela Olahraga, 4(2), $13-25$. https://doi.org/10.26877/jo.v4i2.3678

Freitas, D. L., Lausen, B., Maia, J. A., Gouveia, R., Antunes, A. M., Thomis, M., Lefevre, J., \& Malina, R. M. (2018). Skeletal maturation, fundamental motor skills, and motor performance in preschool children. Scandinavian Journal of Medicine and Science in Sports, 28(11), 2358-2368. https://doi.org/10.1111/sms.13233 
Kamaludin, Ngadiman, Festiawan, R., Kusuma, I. J., \& Febriani, A. R. (2020). Pengembangan Permainan Pecah Piring Sintren: Pemanfaatan Olahraga Tradisional Pada Pembelajaran untuk Meningkatkan Kemampuan Motorik Kasar Anak. TEGAR: Journal of Teaching Physical Education in Elementary SchoolJournal of Teaching Physical Education in Elementary School, 3(5), 37-45.

O' Brien, W., Belton, S., \& Issartel, J. (2016). Fundamental movement skill proficiency amongst adolescent youth. Physical Education and Sport Pedagogy, 21(6), 557571. https://doi.org/10.1080/17408989.2015.101 7451

Priklerová, S., \& Kucharik, I. (2015). Efficiency Of Technical And Tactical Approach To Teaching Minihandball Game Skills In Different Age Categories. Acta Facultatis Educationis Physicae Universitatis Comenianae, 55(2), 132-140. https://doi.org/10.1515/afepuc-2015-0014

Puspitasari, R. N. (2016). Pengaruh permainan tradisional karetan terhadap pembelajaran motorik kasar atletik lompat jauh. Jurnal $P G, 3(1), 9-18$.

Rusmawati, I. (2016). Penerapan Permainan Tradisional Terhadap Gerak Dasar Motorik Siswa Dalam Pembelajaran Pendidikan Jasmani , Olahraga Dan Kesehatan Pada Siswa Kelas V SDN Margomulyo 1 Bojonegoro. Jurnal Pendidikan Olahraga Dan Kesehatan, 4(2), 435-440.

Vlahov, E., Baghurst, T. M., \& Mwavita, M. (2014). Preschool motor development predicting high school health-related physical fitness: A prospective study. Perceptual and Motor Skills, 119(1), 279291. https://doi.org/10.2466/10.25.PMS.119c16z 8

Webster, E. K., \& Ulrich, D. A. (2017). Evaluation of the psychometric properties of the Test of Gross Motor Development-third edition. Journal of Motor Learning and Development, 5(1), 45-58. https://doi.org/10.1123/jmld.2016-0003

Wen, D., Utesch, T., Wu, J., Robertson, S., Liu, J., \& Hu, G. (2019). Effects of different protocols of high-intensity interval training for VO2max improvements in adults: A meta-analysis of randomized controlled trials. Journal of Science and Medicine in Sport, $1-7$. https://doi.org/10.1016/j.jsams.2019.01.013

\section{ACKNOWLEDGEMENTS}

I would like to thank all those who participated in helping to carry out this research, especially from the LPPM of Jenderal Soedirman University who had provided funds to carry out this research. 